\title{
Predicting Exposure to Dust Particles Using Spirometric Index and Perception Studies among Farmers in Selected Farm Settlements in Ogun State, Nigeria
}

\section{Funmilola Felicia Oyebanji ${ }^{1 *}$, Godson Rowland E.E. Ana ${ }^{2}$, Yahaya Mijinyawa ${ }^{3}$, Olusola Olabisi Ogunseye ${ }^{2}$}

\author{
${ }^{1}$ Environmental Management and Toxicology, Federal University of Agriculture, Abeokuta, \\ Nigeria \\ ${ }^{2}$ Environmental Health Sciences, University of Ibadan, Ibadan, Nigeria \\ ${ }^{3}$ Agricultural and Environmental Engineering, University of Ibadan, Ibadan, Nigeria
}

\section{ABSTRACT}

The link between agricultural activities and respiratory disease puts farmers at risk of exposure to particulate matter, potentially reducing lung function. Thus, this comparative cross-sectional work employed a spirometric index and perception studies by conducting interviews and on-thespot lung function tests on 195 farmers living in seven farm settlements of Ogun State and 195 non-farmers living in other areas to assess the ambient levels of the suspended particulate matter and estimate the dust exposure among the first group. The collected data were evaluated through descriptive and inferential statistics and indicated that the majority of the farmers (51.8\%) applied manure, fertilizer and chemical sprays without using personal protective equipment (PPE), although a large percentage of both the farmers (74.9\%) and the non-farmers $(82.1 \%)$ understood that poor air quality could cause respiratory disease. The highest concentrations of the total suspended particles (TSP; $29.89 \pm 23.52 \mu \mathrm{g} \mathrm{m}^{-3}$ ) and $\mathrm{PM}_{10}\left(18.45 \pm 16.97 \mu \mathrm{g} \mathrm{m}^{-3}\right.$ ) were observed during the wet season, whereas that of the $\mathrm{PM}_{2.5}\left(18.45 \pm 11.72 \mu \mathrm{g} \mathrm{m}^{-3}\right)$ was observed during the dry season. Additionally, the mean concentrations of the $\mathrm{PM}_{10}$ and $\mathrm{PM}_{2.5}$ exhibited significant seasonal variation $(p<0.001)$. The forced expiratory volume in 1 second (FEV1) and peak expiratory flow rate (PEFR) also varied considerably between the farmers (1.16 \pm 0.87 and $244.32 \pm 117.96$, respectively) and non-farmers (2.47 \pm 0.87 and $271.29 \pm 104.09$, respectively). Our results showed that the farmers engaged in poor safety practices and possessed reduced lung function compared to non-farmers. Hence, we advise farmers to adopt the use of PPE and follow safety measures. Furthermore, routine assessment of particulate matter and lung function should be encouraged in farm settlements.

Keywords: Farming, Particulate matter, Lung function, Occupational health, Safety practices

\section{INTRODUCTION}

Farming is an array of activities ranging from small-scale hobby farms to massive industrial farms (Elliott and von Essen, 2016). According to DESA (2018), about 57\% of the African population lives in rural areas, and they are mainly farmers. Large-scale emissions from animal husbandry, manure storage and spreading, field cultivation, feed storage, and free-range systems have increased the level of importance of agricultural activities to air pollution. According to the studies of De Jager (2005) and Arslan and Aybek (2012), agricultural activities produce diverse air pollutants such as infectious agents, gases, organic and inorganic particulates and chemicals, posing health risks to farmers, farm workers and surrounding residences (Grimm and Eckhof, 2002). The health 
risks associated with farming may be aggravated when other activities, like charcoal production, are added (Olujimi et al., 2016). Hazardous air pollutants may also be released from farm vehicles and pieces of machinery, which can aggravate cancer risks (Tsai et al., 2019). Land preparation through forest/bush burning emits greater levels of particulate matter pollutants than burning of agricultural residue (Wiriya et al., 2016; Moran et al., 2019).

Air pollution is the most culpable risk factor causing most deaths and injuries following Human Immunovirus/Acquired Immune Deficiency Syndrome (HIV/AIDS), water treatment, and hygiene (Clasen et al., 2014). Respiratory infection of the lower tract (LRTI), tuberculosis, chronic obstructive pulmonary disease (COPD), and lung cancer are the top four respiratory diseases among the 10 causes of death worldwide, according to Lozano et al. (2012). LRTI moved from the fourth position in 2007 to first in 2017 in the hierarchy of causes of infant mortality across the world. In other age brackets, it moved from the third position in 2007 to second in 2017 with a percentage change of $-13.7 \%$ (Murdoch and Howie, 2018). Umoh et al. (2013) also found that farmers accounted for approximately $10 \%$ of 3,490 patients admitted to the medical ward and diagnosed with respiratory diseases in Cross River State, Southeast Nigeria.

Respiratory diseases prevalence data are seldom reported in rural areas, maybe because they do not visit hospitals and the general perception that rural areas are less susceptible to resultant effects of industrialization, which served as pollution and exposure indicators. Previous studies have reported findings that respondents have a perception that rural settings are "clean" spaces with uncontaminated air as opposed to pollution in urban areas (Brody et al., 2004; Brody et al., 2008; Smallbone, 2012; Mally, 2016). This perception was not based on the pollutants concentrations as determined by surveillance instruments, but rather on people's judgments, feelings and attitudes about pollution (Claeson et al., 2013). Sjöberg et al. (2004) observed that perception is a subjective measure of the extent of pollution or exposure and the subsequent effects of the exposure to environmental hazards. The perception that exposure or non-exposure to hazardous substances may or may not cause health symptoms or otherwise (Stenlund et al., 2009). Lloyd et al. (2005) and Brosschot et al. (2006) demonstrated that cardiovascular and inflammatory disorders arise from enhanced neurovascular, cardiovascular, immunological and endocrinological behaviors linked to excessive stress and worry triggered by the perception of adverse exposure impacts. Age, gender, education and health are important social statuses identified to inform or modify perception by predicting health symptoms (Orru et al., 2018). Understanding the view of the public on air quality and associated risks to health are focal points for research into the acceptability of interventions initiatives, including active individual participation (Saksena, 2007; Egondi et al., 2013).

Perceived symptoms are not directly influenced by exposure level; they are rather mediated by perceived pollution and health risks (Claeson et al., 2013). For instance, though the levels of monitored air pollutants around Abeokuta metropolis in Nigeria were low, the perception of the traffic officials indicated relatively severe respiratory (Oyebanji et al., 2019a). Risk perception is multi-faceted with cultural, demographic and political factors that play significant roles in the deviations determined (Egondi et al., 2013). However, with the awareness in the body of knowledge about public perceptions of air quality, the understanding of probable relationships among the exposed people, with concerns about associated health risks are poorly explained. Furthermore, there is also a lack of understanding of the association between perception and onthe-spot measurements of air pollutants levels relating to actual lung function. Therefore, this study predicted exposure to dust particles using spirometric index and perception studies among farmers in selected farm settlements in Ogun State, Nigeria.

\section{METHODS}

\subsection{Description of the Study Area}

This study was conducted in seven selected farm settlements namely, Ado-Odo, Ago Iwoye, Ajegunle, Coker, Ibiade, Ikenne and Sawonjo in Ogun State, Southwest Nigeria (Fig. 1). The farm settlement (FS) scheme is an initiative of the government that involves the procurement and dedication of large expanse of land to boost rural development. These farmers are provided with assets for extensive farming operations and improvement in their living standards. The scheme is 




Fig. 1. Map of Ogun state showing locations of selected farm settlements.

in Israeli Moshavim's model and was established by the Regional Government of Western Nigeria under the leadership of Late Chief Obafemi Awolowo in 1976 (Adegeye, 1974; Familugba, 2016).

Ogun State is situated at $7^{\circ} 00^{\prime} \mathrm{N} 3^{\circ} 35^{\prime} \mathrm{E}$, border Oyo and Osun States in the north, Lagos State in the south, the Republic of Benin to the west and Ondo State to the east. The state falls within the tropical climate system with the raining season commencing from March through November, and the dry season between December and February. The mean annual rainfall ranges between $128 \mathrm{~mm}$ and $105 \mathrm{~mm}$ in the southern and northern parts of the state. The average monthly temperature, by comparison, varies from $23^{\circ} \mathrm{C}$ in July to $32^{\circ} \mathrm{C}$ in February. The agricultural potential of the area is rich, thereby enabling six major cash crops to be cultivated: cassava, cocoa, cotton, kola, oil palm and rice (Oladeebo and Masuku, 2013).

\subsection{Source of Data}

This study employed a cross-sectional design using a comparative approach. It included a questionnaire review, field assessment of particulate matter and exposure evaluation. The subjects were farmers in selected farm settlements, whereas controls were non-farmers living outside the farm settlements.

\subsection{Sampling Procedure}

The sample size was determined based on the non-population-dependent Charan and Biswas (2013) formula suggested for comparison between two classes with a qualitative endpoint with the test power set at $80 \%$ while proportions of farmers and non-farmers applied were 0.06 and 0.024 respectively (Negatu et al., 2016). The sample size was reduced with the equation by Israel (2009) and Ogunseye et al. (2018). The sample reduction yielded a sample size of 390 shared even between the two respondent groups (195 respondents each for farmers and non-farmers). Farmers' population, percentage sampling, proportional allocation of questionnaires among eligible and willing farmers across the FSs are presented in Table S1. 


\subsection{Questionnaire Administration}

The questionnaire was originally written in English and then translated into Yoruba, which is the native language in the field of study. After administration, it was back-translated to English by native Yoruba speakers for accuracy. Trained interviewers gathered data and administered the questionnaire to participants. The first portion of the questionnaire evaluated the social and demographic characteristics of respondents, the second assessed the occupational history, health, and safety practices, and the third evaluated the perception of respondents to air quality and self-reported respiratory symptoms. Eligible participants included full-time resident farmers who were non-smoking male or females. The latter has been working as farmers within the settlements for not less than five years and demonstrated a willingness to be part of the analysis by endorsing an informed consent form while controls were non-smoking non-farmers residing outside the farm settlements.

\subsection{Particulate Matter Assessment}

Particulate matter measurements were taken thrice at 5-minute intervals in the morning and evening using Thermo Scientific MIE pDR-1500 particulate matter monitor. Sampling points were established within the outdoor premises of farmers' residence and taken during the dry (December 2017-February 2018) and wet (May-July 2018) seasons.

\subsection{Lung Function Assessment and Body Mass Index}

Lung function assessment was carried out through spirometry. Spirometry involves the measuring of breath through the amount and speed of air that a person can inhale and exhale. Lung function status was assessed based on the results of forced expiratory volume in one second $\left(\mathrm{FEV}_{1}\right)$ and peak expiratory flow rate (PEFR) using a calibrated PiKo-1 spirometer. For comparison with standards, anthropometric parameters such as height, age, weight and sex were obtained because the thresholds for obstructive lung disease differ by body mass index (BMI) (CDC, 2012). Standard spirometry requires the subject to forcefully exhale the best volume of air possible after taking in a full deep breath. The forced expiratory maneuver is the participant's effort. Lung function assessment was performed in the field by the principal investigator at the close of the day's work in the evening.

The actual $\mathrm{FEV}_{1}$ and PEFR were compared with expected values based on the height and age of respondents. The calculation of the expected values of FEV 1 and PEFR are presented in Eqs. (1) and (2):

$\mathrm{FEV}_{1}(\mathrm{~L})=0.040 \mathrm{H}-0.021 \mathrm{~A}-3.13$

$\operatorname{PEFR}\left(\mathrm{L} \mathrm{s}^{-1}\right)=0.071 \mathrm{H}-0.035 \mathrm{~A}-1.82$

where $\mathrm{FEV}_{1}$ is forced expiratory volume in 1 second in liters (L), PEFR is peak expiratory flow rate in liters per second $\left(\mathrm{L} \mathrm{s}^{-1}\right), \mathrm{H}$ is height in $\mathrm{cm}$, and $\mathrm{A}$ is age in years (Ingle and Nilesh, 2005).

\subsection{Data Analysis}

Data were analyzed for simple descriptive (mean \pm standard deviation (SD) and inferential ( $t$-test, chi-square, Fisher's exact test and simple linear regression) statistics using Statistical Package for the Social Sciences (SPSS) version 22. The proportion was used to summarize socio-demographic characteristics of respondents, occupational history and safety practices of farmers, perception of respondents on health problems and related symptoms, and knowledge of respondents on environmental hazards. The Fisher's exact test and chi-square were used to determine the association between risk factors in farming and lung function, while simple linear regression determined the relationship between particulate matter concentrations and lung function.

\subsection{Quality Assurance and Control}

All the measuring instruments were properly calibrated during the period of sampling. The particulate matter sampler was fitted with three cyclones specific for each particle size, namely, total suspended particles (TSP) and particulate matter $\left(\mathrm{PM}_{10}\right.$ and $\mathrm{PM}_{2.5}$ ). Each parameter was 
monitored after changing the filter paper to take a new reading at different sampling points. The lung function maneuver was demonstrated by the researcher, after which respondents were asked to sit comfortably to carry out their maneuvers. The best result was recorded for each respondent after 3-4 spirometric maneuvers.

\section{RESULTS AND DISCUSSION}

\subsection{Socio-demographic Characteristics of Respondents}

Table S2 shows the socio-demographic characteristics of respondents. A large fraction of farmers and non-farmers were above 50 years $(43.1 \%$ and $37.4 \%)$, males $(72.3 \%$ and $62.1 \%)$, married (76.9 \% and $75.9 \%$ ), with secondary education ( $42.6 \%$ and $43.1 \%$ ) and from Yoruba tribe $(74.4 \%$ and $86.7 \%)$ respectively. Studies on Icelandic, Nigerian and Irish farmers by Sigurdarson et al. (2008), Desalu et al. (2014) and Cushen et al. (2016), respectively reported similar age patterns. Old-age dominance in farming is usually a characteristic of communities with a high rate of urban migration. The high proportion of male farmers was expected, because it is a cultural and religious practice, and considering the nature of activities involved (Adesuyi et al., 2018). Women do assist their husbands, particularly in processing and sale of farm produce, and often consider themselves farmers. A similar result was reported by Auma et al. (2010) and Negatu et al. (2018) among Kenyan and Ethiopian farmers, respectively, where the majority of farmers have male-headed households. The highest level of education of most farmers was secondary education in agreement with the study of Adesuyi et al. (2018). Low educational attainment of farmers could affect their capabilities to perform vital tasks such as calibration of sprayers and understanding manufacturer's specifications for mixing pesticides and fertilizers. Unsafe handling of potentially hazardous chemical substances and poor operational procedures portend risks for these farmers (Okoffo et al., 2016). Education is crucial for an individual's overall behavior and dispositions towards the adoption of agriculturalrelated innovations (Ashburner and Friedrich, 2001). Meanwhile, the high percentage of Yoruba among respondents may be because the FSs under consideration are situated in the southwestern region or probable preferential allocation of land in farm settlements to indigenes. Majority of the farmers (47.2\%) lived in the farm settlements for at least 21 years while most of the nonfarmers (41.5\%) were civil servants.

\subsection{Occupational History and Safety Practices of Respondents}

Table S3 shows the occupational history and safety practices of farmers. Majority of farmers were crop farmers (56.4\%). The predominance of crop farming may be due to the arable nature of soils in the region and reduced necessity for any additional input. Most of the farmers were engaged in farming for over 20 years (53.3\%) and worked for more than 8 hours per day (54.4\%). Results showed that majority of the farmers (70.8\%) apply manure and fertilizer to their crops, while 25.6\% applied Nitrogen Phosphorus and Potassium (NPK) fertilizer strictly. Results also showed that some farmers apply fertilizers in combination. Furthermore, $83.6 \%$ of farmers apply chemical spray for the control of pests, while $63.1 \%$ apply these chemicals themselves. About $51.8 \%$ of the farmers do not use personal protective equipment (PPE) during the application of these chemicals, and hence they were susceptible to adverse health conditions.

Continuous cultivation of land without recourse to fallow periods may lead to a decline in soil viability over time, thereby necessitating indiscriminate use of manures and fertilizers. Also, preservation of harvested crops and protection of plants against pest infestation are both increasing the usage of pesticides on the field and storage areas. Besides, the combination of fertilizer types is common practice across the farm settlements. This practice may be risky according to the study of Rahman et al. (2007), where a greater proportion of acute respiratory infections were in workers exposed to urea in ammonia plant than the unexposed workers. The study of Adesuyi et al. (2018) corroborated the negligence of farmers in under-utilization of PPE during fertilizer and pesticide application, while Linaker and Smedley (2002) identified the non-usage of PPE as one of the predisposing factors leading to various health challenges in agriculture. The health challenges could appear in the form of various hypersensitivities ranging from throat, chest, eye and skin irritations. Farmers reported these conditions immediately after the application of fertilizer or pesticide. Greskevitch et al. (2008) reported that these hypersensitivities might lead to mortality. They showed 
that mortality rate was significantly elevated for multiple respiratory conditions, $10-50$-fold hypersensitivity and pneumonitis occurring above expectation in livestock and crop farmworkers.

\subsection{Perception of Respondents on Health Problems and Knowledge of Environmental Hazards}

Perception of respondents on health problems and related symptoms is shown in Table 1. A small proportion of farmers were diagnosed with some health conditions including allergies (15.4\%),

Table 1. Perception of respondents on health problems and related symptoms.

\begin{tabular}{|c|c|c|c|}
\hline Perceived health problems & Level of severity & Farmers (\%) & Non-farmers (\%) \\
\hline \multirow[t]{4}{*}{ Cough } & Not experienced & $105(53.8)$ & $100(51.3)$ \\
\hline & Severe & $20(10.3)$ & $4(2.1)$ \\
\hline & Moderate & $50(25.6)$ & $87(44.6)$ \\
\hline & Minimal & $20(10.3)$ & $4(2.1)$ \\
\hline \multirow[t]{4}{*}{ Shortness of breath } & Not experienced & $154(79.0)$ & $135(69.2)$ \\
\hline & Severe & $11(5.6)$ & - \\
\hline & Moderate & $19(9.7)$ & $58(29.7)$ \\
\hline & Minimal & $11(5.6)$ & $2(1.0)$ \\
\hline \multirow[t]{4}{*}{ Sore throat } & Not experienced & $140(71.8)$ & $181(92.8)$ \\
\hline & Severe & $9(4.6)$ & - \\
\hline & Moderate & $28(14.4)$ & $13(6.7)$ \\
\hline & Minimal & $18(9.2)$ & $1(0.5)$ \\
\hline \multirow[t]{4}{*}{ Sneezing } & Not experienced & $75(38.5)$ & $180(92.3)$ \\
\hline & Severe & $32(16.4)$ & - \\
\hline & Moderate & $72(36.9)$ & $13(6.7)$ \\
\hline & Minimal & $16(8.2)$ & $2(1.0)$ \\
\hline \multirow[t]{4}{*}{ Asthma } & Not experienced & 165 (84.6) & $169(86.7)$ \\
\hline & Severe & $11(5.6)$ & - \\
\hline & Moderate & $13(6.7)$ & $25(12.8)$ \\
\hline & Minimal & $6(3.1)$ & $1(0.5)$ \\
\hline \multirow[t]{4}{*}{ Vomiting } & Not experienced & $173(88.7)$ & $186(95.4)$ \\
\hline & Severe & $3(1.5)$ & - \\
\hline & Moderate & $12(6.2)$ & $5(2.6)$ \\
\hline & Minimal & $7(3.6)$ & $4(2.1)$ \\
\hline \multirow[t]{4}{*}{ Nausea } & Not experienced & $136(69.7)$ & 189 (96.9) \\
\hline & Severe & $14(7.2)$ & - \\
\hline & Moderate & $23(11.8)$ & $5(2.6)$ \\
\hline & Minimal & $22(11.3)$ & $1(0.5)$ \\
\hline \multirow[t]{4}{*}{ Headache } & Not experienced & 68 (34.9) & $177(90.8)$ \\
\hline & Severe & $32(16.4)$ & $2(1.0)$ \\
\hline & Moderate & $67(34.4)$ & $8(4.1)$ \\
\hline & Minimal & $28(14.4)$ & $8(4.1)$ \\
\hline \multirow[t]{4}{*}{ Chest pain } & Not experienced & $144(73.8)$ & $159(81.5)$ \\
\hline & Severe & $12(6.2)$ & $2(1.0)$ \\
\hline & Moderate & $27(13.8)$ & $4(2.1)$ \\
\hline & Minimal & $12(6.2)$ & $30(15.4)$ \\
\hline \multirow[t]{4}{*}{ Dermatitis } & Not experienced & $145(74.4)$ & 189 (96.9) \\
\hline & Severe & $11(5.6)$ & - \\
\hline & Moderate & $23(11.8)$ & - \\
\hline & Minimal & $16(8.2)$ & $6(3.1)$ \\
\hline \multirow[t]{4}{*}{ Eye irritation } & Not experienced & $125(64.1)$ & $195(100)$ \\
\hline & Severe & $26(13.3)$ & - \\
\hline & Moderate & 35 (17.9) & - \\
\hline & Minimal & $9(4.6)$ & - \\
\hline
\end{tabular}


asthma (6.2\%), conjunctivitis (5.1\%), chest conditions (4.1\%), emphysema (3.6\%), bronchitis (1.5\%) and laryngitis $(0.5 \%)$. However, in comparison, $33.8 \%, 15.4 \%$ and $9.2 \%$ of the non-farmers reported being diagnosed with chest conditions, allergies and conjunctivitis, respectively.

Table 2 presents the knowledge of respondents on environmental hazards. About $70.8 \%$ and $81.0 \%$ of farmers and non-farmers respectively have heard about outdoor air quality. A large percentage of farmers $(74.9 \%)$ and non-farmers $(82.1 \%)$ know that poor air quality can lead to respiratory diseases. Most farmers were aware that smoke, dust, dirty environment (82.6\%), fuel dispensing $(70.3 \%)$, fertilizer application $(69.2 \%)$, chemical spraying $(75.4 \%)$, processing of farm produce $(73.3 \%$ ) and bush burning (71.8\%) could affect air quality (Rizk et al., 2002; Hamid et al., 2010; Savci, 2012; Reynolds et al., 2015; Alenezi and Aldaihan, 2019; Oyebanji et al., 2019b).

\subsection{Seasonal Particulate Matter Concentrations across Farm Settlements}

Table 3 shows mean seasonal particulate matter concentrations across farm settlements. TSP and $\mathrm{PM}_{10}$ had the highest concentrations $\left(29.89 \pm 23.52 \mu \mathrm{g} \mathrm{m}^{-3}\right.$ and $\left.18.45 \pm 16.97 \mu \mathrm{g} \mathrm{m}^{-3}\right)$ during the wet season, while the highest $\mathrm{PM}_{2.5}$ peak $\left(18.45 \pm 11.72 \mu \mathrm{g} \mathrm{m}^{-3}\right)$ was observed in the dry season. These values were within permissible World Health Organization (WHO) limits (WHO, 2005). However, there were significant variations in mean seasonal concentrations of $\mathrm{PM}_{10}$ and $\mathrm{PM}_{2.5}(\mathrm{p}<$ 0.001). Higher $\mathrm{PM}_{10}$ concentration detected during the wet season was in disagreement with the studies by Abdullah et al. (2011) and Ana and Umar (2013) in Malaysia and Nigeria, respectively. The high particulate matter concentration may be attributed to the storage of poultry feed in the indoor spaces, which leads to emission of particles of varying sizes, which are not season-specific. According to Arhami et al. (2009), particulate pollutants should not be interpolated because of the presence of gaseous co-pollutants and associated resultant health risks. Particulates are extremely important in air quality, since their constituents may constitute both chronic and acute health risks depending on the source or activities producing them (Kelly and Fussell, 2015). They could contain organic carbon, nitrates, trace elements, elemental carbon and sulfates at varying

Table 2. Knowledge of respondents on environmental hazards.

\begin{tabular}{|c|c|c|c|}
\hline Variable & Subgroups & Farmers (\%) & Non-farmers (\%) \\
\hline \multirow[t]{2}{*}{ Have you heard about outdoor air quality? } & No & $57(29.2)$ & $37(19.0)$ \\
\hline & Yes & $138(70.8)$ & $158(81.0)$ \\
\hline \multirow{2}{*}{$\begin{array}{l}\text { Do you know that poor outdoor air quality can cause } \\
\text { respiratory diseases? }\end{array}$} & No & $49(25.1)$ & 35 (17.9) \\
\hline & Yes & 146 (74.9) & $160(82.1)$ \\
\hline \multirow{2}{*}{$\begin{array}{l}\text { Are you aware that dirty environment, smoke, and dust affect } \\
\text { outdoor air quality? }\end{array}$} & No & $34(17.4)$ & $19(9.7)$ \\
\hline & Yes & $161(82.6)$ & $176(90.3)$ \\
\hline \multirow{2}{*}{$\begin{array}{l}\text { Do you know that dispensing fuel such as petrol can affect air } \\
\text { quality }\end{array}$} & No & $58(29.7)$ & $53(27.2)$ \\
\hline & Yes & $137(70.3)$ & $142(72.8)$ \\
\hline \multirow[t]{2}{*}{ Do you know that fertilizer application can affect air quality? } & No & $60(30.8)$ & $49(25.1)$ \\
\hline & Yes & $135(69.2)$ & 146 (74.9) \\
\hline \multirow[t]{2}{*}{ Do you know that chemical spraying can affect air quality? } & No & $48(24.6)$ & $43(22.1)$ \\
\hline & Yes & $147(75.4)$ & 152 (77.9) \\
\hline \multirow{2}{*}{$\begin{array}{l}\text { Do you know that the processing of farm produce like grinding } \\
\text { can affect air quality? }\end{array}$} & No & $52(26.7)$ & $44(22.6)$ \\
\hline & Yes & $143(73.3)$ & $151(77.4)$ \\
\hline \multirow[t]{2}{*}{ Do you know that bush burning can affect air quality? } & No & $55(28.2)$ & $41(21.0)$ \\
\hline & Yes & $140(71.8)$ & $151(78.9)$ \\
\hline
\end{tabular}

Table 3. Mean \pm SD seasonal particulate matter concentrations across farm settlements.

\begin{tabular}{llll}
\hline Season/Others & TSP $\left(\mu \mathrm{g} \mathrm{m}^{-3}\right)$ & $\mathrm{PM}_{10}\left(\mu \mathrm{g} \mathrm{m}^{-3}\right)$ & $\mathrm{PM}_{2.5}\left(\mu \mathrm{g} \mathrm{m}^{-3}\right)$ \\
\hline Wet & $29.89 \pm 23.52$ & $18.45 \pm 16.97$ & $11.62 \pm 10.49$ \\
Dry & $29.75 \pm 18.94$ & $11.85 \pm 8.75$ & $18.45 \pm 11.72$ \\
WHO (2005) & & 50 & 25 \\
p value & $0.841^{\mathrm{a}}$ & $<0.0001$ & $<0.0001$ \\
\hline
\end{tabular}

${ }^{a}$-value not significant, SD: standard deviation. 
levels and concentrations (Sawant et al., 2004; Cao et al., 2005). Organic carbon in particulates may contribute to bacterial propagation and aid their transmission (Shrimandilkar, 2013). Furthermore, at about $150^{\circ} \mathrm{C}$, inorganic gases such as $\mathrm{CO}, \mathrm{CO}_{2}, \mathrm{NO}_{2}$ and $\mathrm{NH}_{3}$ are usually emitted when dust particles are present on heated surfaces like local stoves (Kavouras and Stephanou, 2002).

Researches have shown that several non-agricultural air pollution sources such as cooking oil fumes, biomass (burning of refuse), wood smoke and generator use may affect air quality and lead to aggravated pulmonary dysfunction and lung inflammation (Ezzati and Kammen, 2001; Ibhazehiebo et al., 2007; Barone-Adesi et al., 2012; Adewole and Desalu, 2013). Exposure to wood smoke poses a greater health risk (Díaz-Robles et al., 2015).

\subsection{Anthropometric Parameters and Lung Function Status of Respondents}

Table 4 shows the anthropometric parameters and lung function of respondents. The average height $(\mathrm{m})$ of farmers and non-farmers were $1.71 \pm 1.1$ and $1.72 \pm 1.2$ respectively, while the mean body weights $(\mathrm{kg})$ were $64.45 \pm 9.87$ and $62.89 \pm 11.34$ respectively. The average BMls $\left(\mathrm{kg} \mathrm{m}^{-2}\right)$ were $22.11 \pm 3.79$ for farmers and $21.62 \pm 4.60$ for non-farmers. The FEV ${ }_{1}(\mathrm{~L})$ for farmers and non-farmers were $1.16 \pm 0.87$ and $2.47 \pm 0.87$, respectively, while the PEFR $\left(\mathrm{L} \mathrm{min}^{-1}\right)$ for farmers and non-farmers were $244.32 \pm 117.96$ and $271.29 \pm 104.09$ respectively. The t-test revealed significant difference between the FEV $1(p<0.01)$ and PEFR $(p<0.05)$ of farmers and non-farmers. The majority of farmers, $90.3 \%$ and $97.4 \%$, recorded $\mathrm{FEV}_{1}$ and PEFR lower than expected (LTEV) respectively, while $57.9 \%$ and $96.9 \%$ of non-farmers also recorded FEV $\mathrm{F}_{1}$ and PEFR lower than expected values, respectively.

Table 5 shows an association between $\mathrm{FEV}_{1}$ and risk factors in the farming profession. Results showed that there was a relationship between $\mathrm{FEV}_{1}$ and farming category (chi-square 9.325, $\mathrm{p}<$ 0.01 ), evidence of mold presence, water leaks and moisture in the building (chi-square 5.881, $p$ $<0.05$ ), year occupied building was built (chi-square 11.520, $p<0.01$ ) and frequency of daily hand washing (chi-square 14.529, $\mathrm{p}<0.01$ ). Farmers who stayed between 8-20 years in a building were 1.2 times more at risk of having $\mathrm{FEV}_{1}$ lower than expected value than those who have stayed above 20 years in a building (Table S4). This result is at variance with that reported by National Health Service (NHS) (2017) where buildings built between the 1970s-1990s are capable of increasing the risk of occupants to having asbestosis while a study by Gan et al. (2017) also attributed chronic respiratory diseases with older populations with the assumption that they are not likely to change residences.

Fisher's exact test showed that there is a relationship between PEFR and fuel dispensing, processing and grinding of farm produce and duration of stay in the building (Table 6). Farmers who dispense fuel were 10 times more likely than those who do not to have PEFR lower than the expected value (Fisher's exact test, $\mathrm{p}=0.028$; 95\% Critical Interval $(\mathrm{Cl})$ : 0.011-0.908, Odd Ratio (OR): 10.1), while farmers involved in grinding and processing of farm produce were 12 times more likely to have PEFR value that is lower than the expected (Fisher's exact test, $p=0.019 ; 95 \%$ $\mathrm{Cl}$ : 0.009-0.775 OR: 11.8).

The results obtained from this study showed a significantly lowered FEV 1 among farmers

Table 4. Anthropometric parameters and lung function of respondents.

\begin{tabular}{|c|c|c|c|c|c|c|}
\hline Variables & Subgroups & Range & Observed mean \pm SD & $p$-value & $\%$ LTEV & $\%$ HTEV \\
\hline \multirow[t]{2}{*}{ Height (m) } & Farmers & $1.43-1.81$ & $1.71 \pm 1.1$ & $0.877^{a}$ & & \\
\hline & Non-Farmers & $1.38-1.75$ & $1.72 \pm 1.2$ & & & \\
\hline \multirow[t]{2}{*}{ Weight (kg) } & Farmers & $38.00-96.00$ & $64.45 \pm 9.87$ & $0.148^{\mathrm{a}}$ & & \\
\hline & Non-Farmers & $38.00-96.00$ & $62.89 \pm 11.34$ & & & \\
\hline \multirow[t]{2}{*}{$\mathrm{BMI}\left(\mathrm{kg} \mathrm{m}^{-2}\right)$} & Farmers & $15.52-36.78$ & $22.11 \pm 3.79$ & $0.253^{\mathrm{a}}$ & & \\
\hline & Non-Farmers & $11.92-39.68$ & $21.62 \pm 4.60$ & & & \\
\hline \multirow[t]{2}{*}{$\mathrm{FEV}_{1}(\mathrm{~L})$} & Farmers & $0.02-5.05$ & $1.16 \pm 0.87$ & 0.000 & $176(90.3 \%)$ & 19 (9.7\%) \\
\hline & Non-Farmers & $0.75-5.03$ & $2.47 \pm 0.87$ & & $113(57.9 \%)$ & 82 (42.1\%) \\
\hline \multirow[t]{2}{*}{$\operatorname{PEFR}\left(\mathrm{L} \mathrm{min}^{-1}\right)$} & Farmers & $0.39-5.95$ & $244.32 \pm 117.96$ & 0.017 & $190(97.4 \%)$ & $5(2.6 \%)$ \\
\hline & Non-Farmers & $104.00-595.00$ & $271.29 \pm 104.09$ & & 189 (96.9\%) & $6(3.1 \%)$ \\
\hline
\end{tabular}

a $p$-value not significant, HTEV: Higher than expected value; LTEV: Lower than expected value. 
Table 5. Associations between $\mathrm{FEV}_{1}$ and risk factors in farming.

\begin{tabular}{|c|c|c|c|c|c|}
\hline \multirow{2}{*}{ Risk Factors } & \multirow{2}{*}{ Responses } & \multicolumn{2}{|c|}{$\mathrm{FEV}_{1}$} & \multirow{2}{*}{ Chi-square } & \multirow{2}{*}{$P$} \\
\hline & & LTEV & HTEV & & \\
\hline \multirow[t]{3}{*}{ Farming category } & Crop production & $104(94.5 \%)$ & $6(5.5 \%)$ & 9.325 & 0.009 \\
\hline & Livestock & $13(72.2 \%)$ & $5(27.8 \%)$ & & \\
\hline & Both & $59(88.1 \%)$ & $8(11.9 \%)$ & & \\
\hline \multirow{2}{*}{$\begin{array}{l}\text { Evidence of mould presence, water } \\
\text { leaks and moisture in building }\end{array}$} & No & $130(93.5 \%)$ & $9(6.5 \%)$ & 5.881 & 0.015 \\
\hline & Yes & $46(82.1 \%)$ & $10(17.9 \%)$ & & \\
\hline \multirow[t]{4}{*}{ Year occupied building was built } & Before 1960-1975 & 119 (93.0 \%) & $9(7.0 \%)$ & 11.52 & 0.003 \\
\hline & 1976-2009 & $51(89.5 \%)$ & $6(10.5 \%)$ & & \\
\hline & After 2009 & $6(60.0 \%)$ & $4(40.0 \%)$ & & \\
\hline & Once & 75 (97.4\%) & $2(2.6 \%)$ & & \\
\hline \multirow[t]{2}{*}{ Frequency of daily hand washing } & Twice or thrice & $68(81.0 \%)$ & $16(19.0 \%)$ & 14.529 & 0.001 \\
\hline & More than three times & $33(97.1 \%)$ & $1(2.9 \%)$ & & \\
\hline
\end{tabular}

HTEV: Higher than expected value; LTEV: Lower than expected value.

Table 6. Associations between PEFR and risk factors in farming.

\begin{tabular}{|c|c|c|c|c|c|}
\hline \multirow{2}{*}{ Risk Factors } & \multirow{2}{*}{ Responses } & \multicolumn{3}{|c|}{ PEFR } & \multirow{2}{*}{ Fisher's Exact Test } \\
\hline & & LTEV & HTEV & Total & \\
\hline \multirow[t]{2}{*}{ Fuel dispensing } & No & 54 (93.1\%) & $4(6.9 \%)$ & $58(100 \%)$ & $\begin{array}{l}P=0.028 ; 95 \% \mathrm{Cl}: 0.011- \\
\quad 0.908 \text { OR: } 10.1\end{array}$ \\
\hline & Yes & 136 (99.3\%) & $1(0.7 \%)$ & 137 (100\%) & \\
\hline \multirow{2}{*}{$\begin{array}{l}\text { Processing and grinding of } \\
\text { farm produce }\end{array}$} & No & $48(92.3 \%)$ & $4(7.7 \%)$ & $52(100 \%)$ & \\
\hline & Yes & $142(99.3 \%)$ & $1(0.7 \%)$ & $143(100 \%)$ & $\begin{array}{l}P=0.019 ; 95 \% \mathrm{Cl}: 0.009- \\
\quad 0.775 \text { OR: } 11.8\end{array}$ \\
\hline
\end{tabular}

HTEV: Higher than expected value; LTEV: Lower than expected value.

compared to non-farmers. This result is in line with studies in Ethiopia by Negatu et al. (2018) and Mekonnen and Agonafir (2002). These studies focused on pesticide application, while the present study considered the total work system of farmers. Similarly, a study in the Netherlands showed an exposure-dependent association between occupational pesticide exposure and reduction in $\mathrm{FEV}_{1}$ (De Jong et al., 2014). Apart from the pesticide application, another risk factor is mineral fertilizer handling (Rahman et al., 2007; Hovland et al., 2013).

The lowest FEV 1 and PEFR of farmers were taken at Ibiade while the highest FEV 1 and PEFR were documented at Ajegunle and Ikenne, respectively. The questionnaire analysis revealed that Ibiade is a typical crop farming settlement with a large-scale production of kernels for palm oil and visible smoke plume arising from biomass used as a source of fuel. At the same time, Ajegunle and Ikenne were mostly characterized by extensive animal husbandry (poultry and piggery). The lung function results implied that extensive animal husbandry was likely to present a reduced risk of lung dysfunction than crop production. A study by Mackiewicz et al. (2015) showed a similar result, where the highest number of work-related respiratory symptoms was in crop farming, while it was lower in the piggeries and horse stables workers. These assertions were at variance with a study by Faria et al. (2006) in southern Brazil, which reported that poultry workers showed more symptoms of chronic respiratory diseases.

Similarly, Mackiewicz et al. (2015) reported that animal-related work settings resulted in a high load of bio-aerosols. A study by Akpinar-Elci et al. (2017) demonstrated that high dust characterized by spice production is responsible for increased lung dysfunction among workers. Furthermore, a study by Faria et al. (2006) revealed that farmers exposed to high dust concentration showed $70 \%$ increased risk of asthma symptoms, while Oluwole et al. (2013) research work agreed that biomass fuel utilization was associated with pulmonary dysfunction and inflammation of the airways.

Additionally, several wood smoke components $\left(\mathrm{SO}_{2}, \mathrm{NO}_{2}\right.$ and particulate matter) could be released, especially during the processing of farm produce and impacting adversely on lung function by aggravating respiratory symptoms (Gong, 1992). The passage of dust particles could 
Table 7. Linear relationship between lung function and particulate matter concentrations.

\begin{tabular}{llll}
\hline$Y$ & $X$ & Linear Curve Equation & $R^{2}$ \\
\hline PEFR & $\mathrm{PM}_{2.5}$ & $\mathrm{Y}=0.2673 \mathrm{X}+239.88$ & 0.0007 \\
PEFR & $\mathrm{PM}_{10}$ & $\mathrm{Y}=-1.687 \mathrm{X}+274.66$ & 0.0363 \\
PEFR & TSP & $\mathrm{Y}=-0.5673 \mathrm{X}+263.66$ & 0.0105 \\
FEV $_{1}$ & $\mathrm{PM}_{2.5}$ & $\mathrm{Y}=-0.0006 \mathrm{X}+1.1656$ & 0.000006 \\
FEV & $\mathrm{PM}_{10}$ & $\mathrm{Y}=-0.0068 \mathrm{X}+1.2778$ & 0.0107 \\
FEV & $\mathrm{TSP}$ & $\mathrm{Y}=-0.0033 \mathrm{X}+1.2699$ & 0.0067 \\
\hline
\end{tabular}

exacerbate inflammatory reactions resulting in fibrosis of the lungs and $\mathrm{FEV}_{1}$ values reduction in (Longo et al., 2012).

The negative impacts of pesticide handling and use were found to be a result of poor hygiene practices in tandem with the study by Atreya et al. (2012). The severity of post-pesticide exposure symptoms is highly dependent on the type of pesticide. According to Atreya et al. (2012), mild impairment of the acetylcholinesterase expression activity was experienced after exposure to organophosphate pesticides, while exposure to the pyrethroid insecticides and fungicides lead to acute symptoms. It was difficult to ascertain the type of symptoms and associate them with a type of pesticide because most of the farmers often use a different combination of pesticides to achieve maximum effectiveness.

Table 7 shows the linear relationship between lung function and particulate matter concentrations. Although the correlation coefficients, $R^{2}$ was generally low, PEFR revealed a negative correlation with $\mathrm{PM}_{10}$ and TSP, while $\mathrm{FEV}_{1}$ correlated negatively with $\mathrm{PM}_{2.5}, \mathrm{PM}_{10}$ and TSP. These results are expected because an increase in the concentrations of particulate matter leads to reduction in the lung function on exposed subjects. For example, a study by Olujimi et al. (2016) on charcoal workers reported negative correlations among $\mathrm{PM}_{2.5}, \mathrm{FEV}_{1}$ and PEFR. Weak correlation depicted by $R^{2}$ values was recorded in the linear regression analysis attributable to the levels of particulate matter that were within the permissible threshold set by the World Health Organization (WHO, 2005). Any increase in the levels of particulate matter will lead to the reduced lung function of exposed persons, especially those with sizes less than or equal to $10 \mu \mathrm{m}$ due to the process of action of inhalable dust particles (Chen et al., 2019). It is however noteworthy that the scope of this study could not ascertain causal relationship between exposures, risk factors and outcome variables; hence, further studies are required to determine causality.

\section{CONCLUSIONS}

Employing a spirometric index and perception studies, we predicted dust exposure among farmers living in selected farm settlements of Ogun State, Nigeria. The demographic data revealed that most of the farmers applied manure, fertilizer and chemical sprays without using PPE. Furthermore, a small percentage of the farmers had been diagnosed with health conditions, including allergies, asthma, conjunctivitis, chest conditions, emphysema, bronchitis and laryngitis. However, the non-farmers also reported diagnoses of chest conditions, allergies and conjunctivitis, and a majority in both groups agreed that poor air quality could lead to respiratory disease.

The maximum concentrations of the TSP and $\mathrm{PM}_{10}$ were measured during the wet season, but the peak levels for the $\mathrm{PM}_{2.5}$ were observed during the dry season. All of the values we obtained fell within the permissible limits, despite significant seasonal variation $(p<0.001)$ in the mean concentrations of the $\mathrm{PM}_{10}$ and $\mathrm{PM}_{2.5}$. Nevertheless, we discovered obvious differences in the FEV $_{1}$ and PEFR between the farmers and the non-farmers ( $<0.01$ and $p<0.05$, respectively), although the greater part of either group exhibited lower values than expected. Additionally, negative correlations were found between the PEFR and the concentrations of the PM10 and TSP as well as between the $\mathrm{FEV}_{1}$ and the concentrations of the $\mathrm{PM}_{2.5}, \mathrm{PM}_{10}$ and TSP.

Overall, the farmers engaged in poor safety practices, which resulted in noticeably decreased lung function compared to non-farmers. Thus, routine particulate matter assessment and spirometric evaluation should be encouraged in farm settlements, and the adoption of safety measures, such as using PPE, should be recommended to workers. 
The authors declare no conflict of interest.

\section{ACKNOWLEDGEMENTS}

The authors thank the African Union Commission for the research grant. We also appreciate farmers and non-farmers that participated in this study. Also, the authors are grateful to the anonymous reviewers for their comments and suggestions that eventually improved the quality of this work.

\section{SUPPLEMENTARY MATERIAL}

Supplementary data associated with this article can be found in the online version at https://doi.org/10.4209/aaqr.200509

\section{REFERENCES}

Abdullah, N., Shuhaimi, S., Toh, Y., Shafee, A., Maznorizan, M. (2011). The Study of Seasonal Variation of $\mathrm{PM}_{10}$ Concentration in Peninsula, Sabah and Sarawak. Malaysian Meteorological Department 9, 1-28.

Adegeye, A. (1974). Re-examination of the issues involved in the farm settlement scheme of the western State of Nigeria. Oxf. Agrar. Stud. 3, 79-88. https://doi.org/10.1080/13600817408423819

Adesuyi, A.A., Longinus, N.K., Olatunde, A.M., Chinedu, N.V. (2018). Pesticides related knowledge, attitude and safety practices among small-scale vegetable farmers in lagoon wetlands, Lagos, Nigeria. J. Agric. Environ. Int. Dev 112, 81-99. https://doi.org/10.12895/jaeid.20181.697

Adewole, O.O., Desalu, O.O., Nwogu, K.C., Adewole, T.O., Erhabor, G.E. (2013). Respiratory symptoms and lung function patterns in workers exposed to wood smoke and cooking oil fumes (Mai suya) in Nigeria. Ann. Med. Health Sci. Res. 3, 38-42. https://10.4103/21419248.109475

Akpinar-Elci, M., Bidaisee, S., Nguyen, M.T., Elci, O.C. (2017). Occupational exposure and respiratory health problems among nutmeg production workers in Grenada, the Caribbean. Int. J. Occup. Environ. Health 23, 20-24. https://doi.org/10.1080/10773525.2017.1280948

Alenezi, R.A., Aldaihan, N. (2019). Impact of fuel dispensing stations in the vicinity residential homes on the indoor and outdoor air quality. Int. J. Environ. Sci. Technol. 16, 2783-2796. https://doi.org/10.1007/s13762-018-1834-4

Ana, G., Umar, Z. (2013). Indoor air quality and respiratory symptoms experienced among underfive children in daycare centres in Ibadan north local government area, Oyo State, Nigeria: An unpublished Master's dissertation in the Department of Environmental Health Sciences, University of Ibadan, Nigeria.

Arhami, M., Polidori, A., Delfino, R.J., Tjoa, T., Sioutas, C. (2009). Associations between personal, indoor, and residential outdoor pollutant concentrations: Implications for exposure assessment to size-fractionated particulate matter. J. Air Waste Manage. Assoc. 59, 392-404. https://doi.org/10.3155/1047-3289.59.4.392

Arslan, S., Aybek, A. (2012). Particulate matter exposure in agriculture. in: Haryanto, B. (Ed.), Air Pollution - A Comprehensive Perspective, IntechOpen. https://doi.org/10.5772/50084

Ashburner, J., Friedrich, T. (2001). Improving the handling of pesticides application equipment for the safety of applicators. Pesticide Management in West Africa Newsletter: 9-11.

Atreya, K., Kumar Sitaula, B., Overgaard, H., Man Bajracharya, R., Sharma, S. (2012). Knowledge, attitude and practices of pesticide use and acetylcholinesterase depression among farmworkers in Nepal. Int. J. Environ. Health Res. 22, 401-415. https://doi.org/10.1080/09603123.2011.650154

Auma, J., Langat, J., Ngigi, M. (2010). A comparison of male-female household headship and agricultural production in marginal areas of Rachuonyo and Homabay District, Kenya. Jordan J. Agric. Sci. 6, 601-616. 
Barone-Adesi, F., Chapman, R.S., Silverman, D.T., He, X., Hu, W., Vermeulen, R., Ning, B., Fraumeni, J.F., Rothman, N., Lan, Q. (2012). Risk of lung cancer associated with domestic use of coal in Xuanwei, China: A retrospective cohort study. BMJ 345, e5414. https://doi.org/10.1136/bmj.e 5414

Brody, S.D., Peck, B.M., Highfield, W.E. (2004). Examining localized patterns of air quality perception in Texas: A spatial and statistical analysis. Risk Anal. 24, 1561-1574. https://doi.org/10.1111/j.0272-4332.2004.00550.x

Brody, S.D., Zahran, S., Vedlitz, A., Grover, H. (2008). Examining the relationship between physical vulnerability and public perceptions of global climate change in the United States. Environ. Behav. 40, 72-95. https://doi.org/10.1177/0013916506298800

Brosschot, J.F., Gerin, W., Thayer, J.F. (2006). The perseverative cognition hypothesis: A review of worry, prolonged stress-related physiological activation, and health. J. Psychosom. Res. 60, 113-124. https://doi.org/10.1016/j.jpsychores.2005.06.074

Cao, J., Wu, F., Chow, J., Lee, S., Li, Y., Chen, S., An, Z., Fung, K., Watson, J., Zhu, C. (2005). Characterization and source apportionment of atmospheric organic and elemental carbon during fall and winter of 2003 in Xi'an, China. Atmos. Chem. Phys. 5, 3127-3137. https://doi.org/10.5194/acp-5-3127-2005

Centers for Disease Control and Prevention (CDC) (2012). Chronic obstructive pulmonary disease among adults--the United States, 2011. MMWR 61, 938.

Charan, J., Biswas, T. (2013). How to calculate sample size for different study designs in medical research. Indian J. Psychol. Med. 35, 121. https://doi:10.4103/0253-7176.116232

Chen, C.H., Wu, C. D., Chiang, H.C., Chu, D., Lee, K.Y., Lin, W.Y., Yeh, J.I., Tsai, K.W., Guo, Y.L.L. (2019). The effects of fine and coarse particulate matter on lung function among the elderly. Sci. Rep. 9, 1-8. https://doi.org/10.1038/s41598-019-51307-5

Claeson, A.S., Lidén, E., Nordin, M., Nordin, S. (2013). The role of perceived pollution and health risk perception in annoyance and health symptoms: A population-based study of odorous air pollution. Int. Arch. Occ. Env. Health 86, 367-374. https://doi.org/10.1007/s00420-012-0770-8

Clasen, T., Pruss-Ustun, A., Mathers, C.D., Cumming, O., Cairncross, S., Colford Jr, J.M. (2014). Estimating the impact of unsafe water, sanitation and hygiene on the global burden of disease: Evolving and alternative methods. Trop. Med. Int. Health 19, 884-893. https://doi.org/10.111 1/tmi.12330

Cushen, B., Sulaiman, I., Donoghue, N., Langan, D., Cahill, T., Dhonncha, E.N., Healy, O., Keegan, F., Browne, M., O'Regan, A. (2016). High prevalence of obstructive lung disease in non-smoking farmers: The Irish farmer's lung health study. Respir. Med. 115, 13-19. https://doi.org/10.1016/ j.rmed.2016.04.006

De Jager, A.C. (2005). Exposure of poultry farmworkers to ammonia, particulate matter and microorganisms in the Potchefstroom district, South Africa, North-West University. http://repository.nwu.ac.za/handle/10394/988

De Jong, K., Boezen, H.M., Kromhout, H., Vermeulen, R., Postma, D.S., Vonk, J.M. (2014). Association of occupational pesticide exposure with accelerated longitudinal decline in lung function. Am. J. Epidemiol. 179, 1323-1330. https://doi.org/10.1093/aje/kwu053

Department of Economic and Social Affairs (DESA) (2018). 68\% of the world population projected to live in urban areas by 2050, the UN. United Nations Department of Economic and Social Affairs.

Desalu, O., Busari, O., Adeoti, A. (2014). Respiratory symptoms among crop farmers exposed to the agricultural pesticide in three rural communities in southwestern Nigeria: A preliminary study. Ann. Med. Health Sci. Res. 4, 662-666. https://doi.org/10.4103/2141-9248.139370

Díaz-Robles, L., Cortés, S., Vergara-Fernández, A., Ortega, J.C. (2015). Short term health effects of particulate matter: A comparison between wood smoke and multi-source polluted urban areas in Chile. Aerosol Air Qual. Res. 15, 306-318. https://doi.org/10.4209/aaqr.2013.10.0316

Egondi, T., Kyobutungi, C., Ng, N., Muindi, K., Oti, S., Vijver, S., Ettarh, R., Rocklöv, J. (2013) Community perceptions of air pollution and related health risks in Nairobi slums. Int. J. Environ. Res. Public Health 10, 4851-4868. https://doi.org/10.3390/ijerph10104851

Elliott, L., von Essen, S. (2016). COPD in farmers: What have we learnt? Eur. Respir. Soc. 47, 1618. https://doi.org/10.1183/13993003.01768-2015

Ezzati, M., Kammen, D.M. (2001). Quantifying the effects of exposure to indoor air pollution from 
biomass combustion on acute respiratory infections in developing countries. Environ. Health Perspect. 109, 481-488. https://doi.org/10.1289/ehp.01109481

Familugba, J.O. (2016). Agricultural policies and rural development, the case of southwestern Nigeria, 1945-1960. Int. J. Innovation Educ. Res. 4, 39-53. https://doi.org/10.31686/ijier.vol4. iss 2.515

Faria, N.M.X., Facchini, L.A., Fassa, A.G., Tomasi, E. (2006). Farm work, dust exposure and respiratory symptoms among farmers. Rev. Saúde Públ. 40, 827-836. https://doi.org/10.1590/ S0034-89102006005000006

Gan, W.Q., Sanderson, W.T., Browning, S.R., Mannino, D.M. (2017). Different types of housing and respiratory health outcomes. Prev. Med. Rep. 7, 124-129. https://doi.org/10.1016/j.pmed r.2017.05.018

Gong, J.H. (1992). Health effects of air pollution. A review of clinical studies. Clin. Chest Med. 13, 201-214.

Greskevitch, M., Kullman, G., Bang, K.M., Mazurek, J.M. (2008). Respiratory disease in agricultural workers: Mortality and morbidity statistics. J. Agromedicine 12, 5-10. https://doi.org/10.1080/ 10599240701881482

Grimm, E., Eckhof, W. (2002). Assessment of immission of dust and micro-organisms as part of permitting procedures for livestock management installations-legal basis and methods. in: Hinz, T., Rönnpagel, B., Linke, S., Particulate matter in and from agriculture, Landbauforschung Völkenrode, Sonderheft 235, 7-19.

Hamid, A.A., Usman, L.A., Elaigwu, S.E., Zubair, M.F. (2010). Environmental and health risk of bush burning. Adv. Environ. Biol., 4, 241-249.

Hoek, G., Brunekreef, B., Goldbohm, S., Fischer, P., van den Brandt, P.A. (2002). Association between mortality and indicators of traffic-related air pollution in the Netherlands: A cohort study. Lancet 360, 1203-1209. https://doi.org/10.1016/S0140-6736(02)11280-3

Hovland, K.H., Skogstad, M., Bakke, B., Skare, Ø., Skyberg, K. (2013). Longitudinal lung function decline among workers in a nitrate fertilizer production plant. Int. J. Occ. Environ. Health 19, 119-126. https://doi.org/10.1179/2049396713Y.0000000025

Ibhazehiebo, K., Dimkpa, U., Uche, K., Iyawe, V. (2007). Peak expiratory flow rate and respiratory symptoms following chronic domestic wood smoke exposure in women in Edo, Nigeria. Afr. J. Biomed. Res. 10, 33-39. https://doi.org/10.4314/ajbr.v10i1.48920

Ingle, S.T., Nilesh, W. (2005). 10th Meeting and 16th Mini EURO Conference of the Euro Working Group on Transportation Poznan, Poland, 2005, pp. 99-102.

Israel, G.D. (2009). Determining the sample size. University of Florida IFAS extension. https://edis.ifas.ufl.edu/pd006

Kavouras, I., Stephanou, E. (2002). Gas/particle partitioning and size distribution of primary and secondary carbonaceous aerosols in public buildings. Indoor Air 12, 17-32. https://doi.org/10. 1034/j.1600-0668.2002.120104.x

Kelly, F.J., Fussell, J.C. (2015). Air pollution and public health: Emerging hazards and improved understanding of risk. Environ. Geochem. Health 37, 631-649. https://doi.org/10.1007/s10653015-9720-1

Linaker, C., Smedley, J. (2002). Respiratory illness in agricultural workers. Occ. Med. 52, 451-459. https://doi.org/10.1093/occmed/52.8.451

Longo, D.L., Fauci, A.S., Kasper, D.L., Hauser, S., Jameson, J.L., Loscalzo, J. (2012). Harrison's principles of internal medicine. McGraw-Hill, United States, 1277.

Lozano, R., Naghavi, M., Foreman, K., Lim, S., Shibuya, K., Aboyans, V., Abraham, J., Adair, T., Aggarwal, R., Ahn, S.Y., AlMazroa, M.A. (2012). Global and regional mortality from 235 causes of death for 20 age groups in 1990 and 2010: A systematic analysis for the global burden of disease study 2010. Lancet 380, 2095-2128. https://doi.org/10.1016/S0140-6736(12)61728-0

Mackiewicz, B., Skórska, C., Dutkiewicz, J. (2015). Relationship between concentrations of microbiological agents in the air of agricultural settings and the occurrence of work-related symptoms in exposed persons. Ann. Agric. Environ. Med. 22, 473-477. https://doi.org/10.560 4/12321966.1167717

Mally, K.V. (2016). Perceptions of air quality in Ljubljana. Dela 46, 67-88. https://doi.org/10.4312/ DELA.46.3.67-88

McConnell, R., Shen, E., Gilliland, F.D., Jerrett, M., Wolch, J., Chang, C.C., Lurmann, F., Berhane, 
K. (2014). A longitudinal cohort study of body mass index and childhood exposure to secondhand tobacco smoke and air pollution: The southern California children's health study. Environ. Health Perspect. 123, 360-366. https://doi.org/10.1289/ehp.1307031

Mekonnen, Y., Agonafir, T. (2002). Effects of pesticide applications on respiratory health of Ethiopian farmworkers. Int. J. Occup. Environ. Health 8, 35-40. https://doi.org/10.1179/oeh.2002.8.1.35

Moran, J., NaSuwan, C., Poocharoen, O.O. (2019). The haze problem in Northern Thailand and policies to combat it: A review. Environ. Sci. Policy 97, 1-15. https://doi.org/10.1016/j.envsci.2 019.03.016

Moshammer, H., Hutter, H., Hauck, H., Neuberger, M. (2006). Low levels of air pollution induce changes in lung function in a panel of school children. Eur. Respir. J. 27, 1138-1143. https://doi.org/10.1183/09031936.06.00089605

Murdoch, D.R., Howie, S.R.C. (2018). The global burden of lower respiratory infections: Making progress, but we need to do better. Lancet Infect. Dis. 18, 1162-1163. https://doi.org/10.101 6/S1473-3099(18)30407-9

Negatu, B., Kromhout, H., Mekonnen, Y., Vermeulen, R. (2016). Use of chemical pesticides in Ethiopia: A cross-sectional comparative study on knowledge, attitude and practice of farmers and farmworkers in three farming systems. Ann. Occup. Hyg. 60, 551-566. https://doi.org/10. 1093/annhyg/mew004

Negatu, B., Vermeulen, R., Mekonnen, Y., Kromhout, H. (2018). Neurobehavioural symptoms and acute pesticide poisoning: A cross-sectional study among male pesticide applicators selected from three commercial farming systems in Ethiopia. Occup. Environ. Med. 75, 283-289. http://dx.doi.org/10.1136/oemed-2017-104538

Ogunseye, O.O., Ana, G.R., Uhiara, D.C., Shendell, D.G. (2018). Carboxyhaemoglobin levels among traders exposed to vehicular emissions in three motor parks in Ibadan, Nigeria. J. Environ. Public Health 2018, 9174868. https://doi.org/10.1155/2018/9174868

Okoffo, E.D., Mensah, M., Fosu-Mensah, B.Y. (2016). Pesticides exposure and the use of personal protective equipment by cocoa farmers in Ghana. Environ. Sys. Res. 5, 17. https://doi.org/10. 1186/s40068-016-0068-z

Oladeebo, J.O., Masuku, M.B. (2013). Effect of farmer education and managerial ability on food crop production in Nigeria. J. Econ. Sustain. Dev. 4, 75-82.

Olujimi, O., Ana, G., Ogunseye, O., Fabunmi, V. (2016). Air quality index from charcoal production sites, carboxyhaemoglobin and lung function among occupationally exposed charcoal workers in southwestern Nigeria. Springerplus 5, 1546. https://doi.org/10.1186/s40064-016-3227-9

Oluwole, O., Arinola, G.O., Ana, G.R., Wiskel, T., Huo, D., Olopade, O.I., Olopade, C.O. (2013). Relationship between household air pollution from biomass smoke exposure, and pulmonary dysfunction, oxidant-antioxidant imbalance and systemic inflammation in rural women and children in Nigeria. Global J.Health Sci. 5, 28. https://doi.org/10.5539/gjhs.v5n4p28

Orru, K., Nordin, S., Harzia, H., Orru, H. (2018). The role of perceived air pollution and health risk perception in health symptoms and disease: A population-based study combined with modelled levels of $\mathrm{PM}_{10}$. Int. Arch. Occup. Environ. Health 91, 581-589. https://doi.org/10.1007/s00420018-1303-x

Oyebanji, F., Ana, G., Mijinyawa, Y., Oguntoke, O. (2019b). Evaluating the impact of extensive agricultural activities on indoor gaseous, particulate pollutants and bio-aerosol load. Ethiopian J. Environ. Stud. Manage. 12, 43-55. https://doi.org/10.51406/jagse.v19i1.2020

Oyebanji, F.F., Towolawi, A.T., Ogunyemi, A., Solademi, F. (2019a). Evaluation of perceptive respiratory health problems of traffic officials and vehicular emissions within Abeokuta metropolis. Nigeria J. Sci. Res. 18, 164-176.

Peel, J.L., Tolbert, P.E., Klein, M., Metzger, K.B., Flanders, W.D., Todd, K., Mulholland, J.A., Ryan, P.B., Frumkin, H. (2005). Ambient air pollution and respiratory emergency department visits. Epidemiology 16, 164-174. https://www.jstor.org/stable/20486023

Pickett, W., King, N., Lawson, J., Dosman, J.A., Trask, C., Brison, R.J., Hagel, L., Janssen, I., Team, S.F.I.C.S. (2015). Farmers, mechanized work, and links to obesity. Preventive Med. 70, 59-63. https://doi.org/10.1016/j.ypmed.2014.11.012

Rahman, M.H., Bråtveit, M., Moen, B.E. (2007). Exposure to ammonia and acute respiratory effects in a urea fertilizer factory. Int. J. Occup. Environ. Health 13, 153-159. https://doi.org/10.1179/oe h.2007.13.2.153 
Reynolds, T.W., Waddington, S.R., Anderson, C.L., Chew, A., True, Z., Cullen, A. (2015). Environmental impacts and constraints associated with the production of major food crops in Sub-Saharan Africa and South Asia. Food Sec. 7, 795-822. https://doi.org/10.1007/s12571015-0478-1

Rizk, H.F., El-Abssawy, A.A., Khoder, M.I. (2002). An analysis of pesticide impact on air quality, especially surface ozone. Environ. Manage. Health 13, 152-162. https://doi.org/10.1108/095 66160210424581

Saksena, S. (2007). Public perceptions of urban air pollution with a focus on developing countries. http://www.jstor.com/stable/resrep16045

Savci, S. (2012). Investigation of the effect of chemical fertilizers on the environment. APCBEE Procedia 1, 287-292. https://doi.org/10.1016/j.apcbee.2012.03.047

Sawant, A.A., Na, K., Zhu, X., Cocker, K., Butt, S., Song, C., Cocker III, D.R. (2004). Characterization of $\mathrm{PM}_{2.5}$ and selected gas-phase compounds at multiple indoor and outdoor sites in Mira Loma, California. Atmos. Environ. 38, 6269-6278. https://doi.org/10.1016/j.apcbee.2012.03.047

Shrimandilkar, P.P. (2013). Indoor air quality monitoring for human health. Int. J. Mod. Eng. Res. 3, 891-897.

Sigurdarson, S.T., Gudmundsson, G., Sigurvinsdottir, L., Kline, J.N., Tomasson, K. (2008). Respiratory disorders are not more common in farmers. Results from a study on Icelandic animal farmers. Respir. Med. 102, 1839-1843. https://doi.org/10.1016/j.rmed.2008.07.006

Sjöberg, L., Moen, B.E., Rundmo, T. (2004). Explaining risk perception. An evaluation of the psychometric paradigm in risk perception research. Rotunde publikasjoner Rotunde 84, 55-76.

Smallbone, K. (2012). Individuals interpretation of air quality information: Follow up the investigation into the proposed air quality health advice. Report for DEFRA. http://ukair.defra.gov.uk/library/reports?report_id $=720$

Stenlund, T., Lidén, E., Andersson, K., Garvill, J., Nordin, S. (2009). Annoyance and health symptoms and their influencing factors: A population-based air pollution intervention study. Public Health 123, 339-345. https://doi.org/10.1016/j.puhe.2008.12.021

Tsai, J.H., Gu, W.T., Chung, I., Chiang, H.L. (2019). Airborne air toxics characteristics and inhalation health risk assessment of a metropolitan industrial complex. Aerosol Air Qual. Res. 19, 24772489. https://doi.org/10.4209/aaqr.2019.08.0422

Umoh, V.A., Otu, A., Okpa, H., Effa, E. (2013). The pattern of respiratory disease morbidity and mortality in a tertiary hospital in southern-eastern Nigeria. BMC Pulm. Med. 2013, 581973. https://doi.org/10.1155/2013/581973

Wiriya, W., Chantara, S., Sillapapiromsuk, S., Lin, N.H. (2016). Emission profiles of PM10-bound polycyclic aromatic hydrocarbons from biomass burning determined in the chamber for assessment of air pollutants from open burning. Aerosol Air Qual. Res 16, 2716-2727. https://doi.org/10.4209/aaqr.2015.04.0278

World Health Organization (WHO) (2005). Air quality guidelines - Global update. http://www.who. int/phe/health_topi cs/outdoorair/outdoorair_aqg/en/ (accessed 20 April 2018). 